\title{
HOW NEAR IS A WRITTEN CONSTITUTION?
}

\author{
Rodney Brazier, Professor of Constitutional Law, \\ University of Manchester
}

\section{CONSTITUTION-MAKING}

Politicians are the midwives of constitutional change. Reform cannot come about unless a political party delivers it while in government. All the reforming energies of those outside government are of limited practical significance until that happens. Constitutional change and the political will to achieve it came together when the Labour Party swept to power in May 1997. The Labour Government will take pride in subsequently achieving so much of its constitutional reform programme within the first three sessions of the 1997 Parliament. On a checklist of items derived from its manifesto commitments, everything can receive a tick as having been done or begun. Critics may say with some justice that such a broad-brush conclusion masks the fact that some achievements are rather limited, especially stage one of Lords reform (which was the easy part),${ }^{1}$ or may point out that nothing has been done about changing the voting system for Westminster beyond commissioning the Jenkins Report. ${ }^{2}$ Moreover, for a Government with the largest parliamentary majority in ordinary peacetime conditions at any time in the twentieth century, legislative success in the House of Commons should scarcely be a cause for inordinate congratulation or surprise. Even so, Ministers must have been greatly relieved by the ease with which they achieved their constitutional goals in a largely hostile House of Lords. But it would have been difficult for Conservative peers - who before November 1999 were then the effective majority in that House - to vote down Labour's Bills which had been endorsed by the voters at the General Election, and indeed the Salisbury convention required that they should not do so. ${ }^{3}$ True, Opposition peers tried to delay the passage of the measure of most direct concern to them, the House of Lords Bill. But despite the occasional blustering of the Lord Chancellor and the Leader of the House of Lords about the number of unhelpful amendments that were tabled to that Bill, and the time which it took to deal with them, resort to the Parliament Acts to secure the measure never seemed close, even though (or perhaps because) the Labour Party had obtained manifesto authority to do so if necessary. ${ }^{4}$ The Government's acceptance of the Weatherill amendment which exempted 92 hereditary peers from the axe unquestionably played its part. ${ }^{5}$ And in relation to devolution the Conservative Party's teeth had been drawn by the

1 House of Lords Act 1999.

2 Report of the Independent Commission on the Voting System, Cm 4090 (1998). As will be explained later, the Government has distanced itself from the Commission's main recommendation.

3 Brazier, "Defending the Hereditaries: The Salisbury Convention" [1999] PL 371.

4 New Labour: Because Britain Deserves Better (Labour Party, 1997).

5 Perhaps the Government procured that amendment, rather than just accepted it. The amendment seems to have been arrived at by Lord Irvine and by Lord Cranborne for the Conservative peers, and was then put to Lord Weatherill to present: Andrew Rawnsley, Servants of the People (2000), p 203. 
electoral endorsements of the Government's proposals at the Scottish and Welsh referendums. For on what democratic basis could the Opposition try to thwart plans which had received electoral approval twice, once in Labour's General Election manifesto, and then at referendums?

But at the time of writing (January 2001) the next General Election is almost upon us. Ministers will be giving increasingly more attention to the contents of the manifesto. ${ }^{6}$ From Ministers' perspectives it would be understandable if the material in the manifesto about the constitution offered no more than a period of consolidation rather than further significant reform. In essence, Ministers could assert with some justice that so much has been done in such a short time that the new dispensations should be given time to bed down, and that other reforms need more time for completion. After all, power has been diffused from Westminster to Belfast, Cardiff, Edinburgh, and London - but it is still too early to know how complete or final those devolutions may be $;^{7}$ citizens have easier access to enforcing their rights - but the exact limits of those rights remain tantalizingly unclear; 8 Labour's century-old wish to "do something" about the House of Lords has been granted - but work is still needed to arrive at a final settlement; and so on. Further legislative adjustments to a number of statutes may be needed to reflect experience of the new arrangements, and time is needed to allow that experience to be appreciated. A further scaling-down or reorganization of national ministerial dispositions may be required following the experience of government in Scotland and Wales, involving perhaps the merger of the Scotland Office and the Wales Office under a single Secretary of State. ${ }^{9}$ The bedding-down argument is likely to be strengthened - at any rate to the satisfaction of Ministers and the Labour Party more generally - by a certain fatigue with constitutional matters. Much time - including, in relation to Northern Ireland, the Prime Minister's time - has been expended on constitutional change in Labour's first term. The prospect of taking on anything like similar commitments during a second term in government may be unattractive, especially because not even Ministers claim that constitutional reform excites voters or garners their support. And so on a purely political level the Government may wish to reassure the electorate that its energies in the next Parliament will indeed be concentrated on what new Labour dubs the people's priorities such as health, education, transport, and crime, and Ministers may prefer to deliver that message clearly, unencumbered by further grand constitutional plans. If that overall assessment is right then a commitment - either in the forthcoming General

6 The latest comprehensive statement of Labour Party policy is contained in Building a Future for All: National Policy Forum Reports to Conference (Labour Party, 2000). The document was approved at the party's annual conference in autumn 2000. It is from that paper that most material for the next General Election manifesto will be drawn.

7 Several Orders in Council have been made already under the devolution statutes to adjust powers further between London and the other capitals.

8 See, eg, Hunt, "The 'Horizontal Effect' of the Human Rights Act" [1998] PL 423.

9 Delivering Constitutional Reform (Constitution Unit, 1996). The number of junior Ministers in those two Offices has been reduced already to take account of the reduced workload in Whitehall. The Northern Ireland Office with its own Secretary of State is, however, likely to be needed for the indefinite future given the uncertainty which remains over the stability of the Good Friday agreement. 
Election manifesto, or subsequently - to work towards a written constitution might seem hopelessly unlikely. Or is it? The purpose of this article is to try to answer that question.

\section{REFORMING THE FORM OF THE CONSTITUTION}

One of the lasting achievements of the 1997 Labour Government will be its constitution-making, primarily of course in the sense of giving effect to new constitutional dispensations, but also in the narrow, technical sense of producing new legal rules which prescribe how the state is to be governed. The former is more important in practical and political terms than the latter, but the effect of the latter on the form of the British constitution deserves to be assessed.

As every schoolchild is supposed to know, the United Kingdom does not have a written constitution. ${ }^{10}$ A British citizen has to seek the rules of the constitution in a daunting number of places - legislation, judicial decisions, statements about constitutional conventions, the law and practice of Parliament, European Community law, and so on. It is hardly surprising that the interested citizen will normally leave those sources to one side and rely instead on books written by authoritative writers, and those who aspire to be authoritative. But just listing the primary materials which form the constitution demonstrates the extent to which the British constitution is largely a written one. Indeed, all the sources exist as official statements made by organs of the state, except for conventions, most of which have been reduced to writing only by the unofficial efforts of constitutional commentators. ${ }^{11}$ The British constitution is written, but it is not codified into a single official document, or limited number of such documents, setting out those legal rules which prescribe how the state is to be governed. ${ }^{12}$

In implementing its range of reforms the Labour Government has caused Parliament to enact an additional and substantial corpus of statute law of a constitutional character. While, therefore, the United Kingdom still lacks a codified constitution, it has been given rather more of a written constitution by the addition of sixteen Acts of Parliament which, in whole or in part, add to the British constitution. ${ }^{13}$ Perhaps most importantly towards that end, the

10 For an analysis of that term see Munro, "What is a Constitution?" [1983] PL 563.

11 For an overview see Jaconelli, "The Nature of Constitutional Convention" (1999)

19 Legal Studies 24. Official statements of constitutional conventions include parts of the preamble to the Statute of Westminster 1931, parts of the Ministerial Code (Cabinet Office, 1997), statements in various White Papers confirming the status of Northern Ireland within the United Kingdom, and the devolution conventions arrived at between the British Government and the devolved authorities and published in Memorandums of Understanding.

12 For descriptions of its characteristics, including its "unwritten" nature, see eg S.A. de Smith and R. Brazier, Constitutional and Administrative Law (8th ed, 1998), chapter 1; A.W. Bradley and K. Ewing, Constitutional and Administrative Law (12th ed, 1997), chapter 1; E. Barendt, An Introduction to Constitutional Law (1998), chapter 1.

13 As in constitutional law generally, describing a statute as one of constitutional import can be a matter of choice. But the principal Acts are the Referendums (Scotland and Wales) Act 1997, the Data Protection Act 1997, the Scotland Act 1998, the Government of Wales Act 1998, the Northern Ireland Act 1998, the 
United Kingdom now has the kind of Bill of Rights which features prominently in so many national constitutions, supplied by the Human Rights Act $1998 .{ }^{14}$ The lacuna which had existed in the enforcement of civil rights has now been filled. The devolution statutes have answered - at least for the time being - many long-standing queries about the appropriate relationships between the various parts of Great Britain, and with luck of the United Kingdom, and have redefined the juridical balance between them; ${ }^{15}$ the composition of the national legislature has been radically altered by the House of Lords Act 1999; and so on. There has been an exponential growth in the body of constitutional statute law since 1997, and because statute overrides case law and convention in the constitutional order the new laws represent some of the ground work which would be required for the production of a codified constitution. When it was still in opposition the Labour Party recognized that its legislative programme would have that effect in the narrower sense of the phrase constitution-making. In what was then its main constitutional policy document, A New Agenda for Democracy, adopted four years before coming to power, the party claimed that its changes would be a significant step in the direction of a written constitution, and the paper stated that the party would leave open the question of whether at a later stage progress should be made towards formal codification. ${ }^{16}$ Now that statement needs to be put into context. On the one hand, it was the first move - however tentative - by either of the two big political parties towards the idea of constitutional codification. ${ }^{17}$ On the other hand the statement did not really take account of all the other areas of the constitution which Labour's proposed changes would not affect but which would have to be reassessed and considered for inclusion in any constitutional code. For even after Labour's current reform programme has been fully implemented it would leave vital matters untouched, such as the monarchy, prerogative powers enjoyed by Ministers, the powers of the House of Commons, and the judicial system. Clearly, too, that statement in the policy paper was overterse, in that it ignored other important matters which would be crucial in any codification exercise, such as how and by whom it would be undertaken. Nor did the comments about codification find any place in Labour's 1997 General Election manifesto. Whatever the Labour Party had in mind about revising the formal state of the constitution in 1993, the question which should be addressed now that so much of the party's constitution-making is

Greater London Authority (Referendum) Act 1998, the Human Rights Act 1998, the Regional Development Agencies Act 1998, the European Parliamentary Elections Act 1999, the Greater London Authority Act 1999, the House of Lords Act 1999, the Local Government Act 1999, the Regulation of Investigatory Powers Act 2000, the Political Parties, Elections and Referendums Act 2000, the Disqualifications Act 2000, and the Representation of the People Act 2000.

14 Effect had been given to the European Convention on Human Rights in municipal law in Scotland by the Scotland Act 1998, s 57, in Wales by the Government of Wales Act 1998, s 107, and eventually in Northern Ireland by the Northern Ireland Act 1998, s 24.

15 See Brazier, "The Constitution of the United Kingdom" [1999] Cambridge Law Journal 96.

16 A New Agenda for Democracy (Labour Party, 1993), p 44.

17 The Liberal Democrats, following the policy of their predecessors, want to see a written United Kingdom constitution. See Reforming Governance in the UK: Policies for Constitutional Reform (Policy Paper No 40, 2000). 
in place is what could be done with the legal form of the United Kingdom constitution.

In considering that question four options emerge. The most conservative course - and the one which has been followed for the whole of English and British constitutional history - would be to continue to build on the laws and conventions already in place, altering them only as and when required. Constitutional change has happened in fits and starts, with occasional bursts of legislative activity which has usually been caused by events which forced Governments to act. In the last century it was such reaction which produced, for example, the Parliament Act 1911, votes for women, a new constitution for Ireland (and later Northern Ireland), and so on. That method is reactive and ad hoc, Ministers and Parliament responding to pressure and producing pragmatic solutions as needed. It has been exceptional for one of the two main political parties to go into a General Election offering planned constitutional measures: the present Government is the most notable exception. ${ }^{18}$ It would be perfectly possible for that reactive method to continue to be followed. A second option, however, would be build on the Labour Government's constitution-making through a programme of consolidation. That could be a traditional exercise in statutory consolidation, that is, bringing all related statutory rules together in one statute (or, more likely, a series of statutes). ${ }^{19}$ Such consolidation might be the first step towards the apparent aspiration indicated in Labour's 1993 policy document of working towards a written constitution. There has been little attempt to consolidate constitutional statutes, ${ }^{20}$ the only recent examples being the Representation of the People Act $1983,{ }^{21}$ the Parliamentary Constituencies Act $1986,{ }^{22}$ and the European Parliamentary Elections Bill 1999-2000. ${ }^{23}$ Consolidation work is usually carried out by the Law Commission, with parliamentary time being found for consolidation Bills only where there is a clear need to help the user of the statutes affected. It is hard to make a particularly strong case for constitutional consolidation on that ground. Indeed, depending on how extensive the consolidations were to be, ${ }^{24}$ issues of principle would be thrown up which went way beyond a technical improvement exercise. For instance, would the present controversial religious tests for accession to the Crown be consolidated when there is a

18 Indeed, the only two other main examples are the October 1974 Labour commitment to bring devolution to Scotland and Wales, and the 1983 Conservative pledge to abolish the Greater London Council and the metropolitan county councils.

19 The essence of consolidation is the rational ordering of existing legal rules: it is not to bring about changes to the substance of those rules.

20 See Brazier, "Enacting a Constitution" [1992] Statute Law Review 104 at pp 125127.

21 The Act provided a consolidated statement of electoral law for both parliamentary and local government elections.

22 The purpose of the statute was to consolidate the rules under which parliamentary constituency boundaries are determined.

23 The Bill was designed to bring together all the rules on United Kingdom elections to the European Parliament: it lapsed on prorogation in 2000.

24 There are, for example, about twenty principal Acts relating to Parliament, twelve concerning the Crown, and seven dealing with ministerial offices, which would all be candidates for consolidation. 
principled case for abolition? Consolidation of constitutional law would disclose many similar problems. Overall, the case for simple consolidation is weak.

A third possibility would be codification, not of the whole constitution, but of suitable or desirable areas. ${ }^{25}$ By codification is meant the reduction to coherent legal rules, in a logical and structured form, of all the source material on a given topic, changing the substance where necessary to meet contemporary requirements. In that sense, constitutional codification would be similar to such law reform exercises in other areas, but there would be significant differences. One would be that - unlike all other areas of law the question would have to be addressed of what to do with relevant and important non-legal rules. ${ }^{26}$ No other area of law in the United Kingdom has such a rich gloss of non-legal rules which in practice modify the operation of those rules. In a limited codification, it is true, the problem of how to codify conventions could be avoided by starting the exercise in areas untouched by convention. Another factor which would distinguish constitutional codification from others is the deeply political and sometimes controversial nature of parts of constitutional law. For that reason the task could not be the equivalent of a Law Commission enterprise. ${ }^{27}$ Yet another distinction is that, for codification to be a worthwhile task, the subject-matter needs to be fairly well settled. If there is a prospect of significant subsequent change a resulting code will gather statutory accretions which would spoil the elegance of the final product. ${ }^{28}$ It might be said that the British constitution is too unstable at present for even limited codification to be embarked on now, especially because there are too many key areas (such as the form of the second chamber, and voting reform) which are still in a state of uncertainty.

The fourth and final and the boldest option for the reform of the technical form of the constitution would be to achieve complete codification, that is, a written constitution properly so-called. ${ }^{29}$ Were that to be done the United Kingdom would leave that very exclusive club whose members are the developed states which lack a codified national constitution. New Zealand resigned its membership in 1986 when it passed its Constitution Act; only Israel and the United Kingdom remain in it. I want now to examine in some

25 The merits and demerits of complete as against partial codification (not in the specific context of constitutional law) are examined in J.H. Farrar and A.M. Dugdale, Introduction to Legal Method (2nd ed, 1984), chapter 11. On that issue in the context of criminal law see A.T.H. Smith, "Codification of the Criminal Law: (1) The Case for a Code" [1986] Criminal Law Review 285.

26 This question will be considered in more detail later.

27 For an analysis of the advantages and drawbacks of codification of criminal law (which has resonances with constitutional law in this context) see the Law Commission, A Criminal Code for England and Wales (HC 299 (1988-1989)), paras 2.1-2.28.

28 Of course, all constitutions attract amendments, but it is fair to say that when a national constitution is adopted it is hoped that the substance of its main provisions represent the settled will of its adopters.

29 I have examined at length the technical legislative techniques which would be relevant to the enactment of a codified constitution for the United Kingdom in "Enacting a Constitution" [1992] Statute Law Review 104. 
detail the issues involved in producing a constitutional code for the United Kingdom.

\section{A CONSTITUTIONAL CODE?}

The advantages for a state having a fixed, though amendable, constitution are well-known and need not be rehearsed in any detail. ${ }^{30}$ They include the fulfilment of a natural expectation that the main rules which regulate the governance of a state should be knowable to any citizen, the certainty which flows from having formally-stated and binding rules of constitutional law, ${ }^{31}$ the ability to see the importance of constitutional rules over other rules in a legal system, and usually the protection of those rules, by entrenchment, from what would otherwise be the effective control of the Government of the day through the passage of ordinary legislation. But so far those attributes have not been sufficiently attractive to either of the two main political parties to persuade them to embark on such a momentous reform of the British constitution. Why is that?

Like everyone else the political parties are products of their country's past. English and British constitutional history has brought heavy baggage to be borne by policy-makers and citizens alike. Obviously, no events in that historical sweep have unavoidably required the adoption of a written constitution. Equally obviously, cataclysmic episodes have certainly occurred, such as the triumph of Parliament in the English civil war, and the later crowning of parliamentary sovereignty in 1688; and the state itself has been radically altered by the merger of England and Scotland, and Great Britain with Ireland. ${ }^{32}$ But looked at from the limited perspective of forces which might have produced a written constitution, England and Britain went through such tremors as much as a century too soon. The idea that a state should possess a document containing its basic constitutional rules did not form until the late eighteenth century. France and the American colonies underwent their constitutional upheavals as statesmen came to recognize that such events required the adoption of written statements about a country's constitution, often to be drafted in order to prevent the kind of abuses which had precipitated revolution. Had the seventeenth-century English civil war and revolution occurred a hundred years later, England just might have been swayed by the intellectual movement which saw the necessity for constitutional codes, and she might have resorted to a similar constitutional prescription. But by (say) 1700 the main constitutional arrangements in

30 The case for a new written constitution for the United Kingdom has been argued, inter alia, by Lord Hailsham, Elective Dictatorship (1976) and The Dilemma of Democracy (1978) - although he was less sure by the time he published On The Constitution (1992); Lord Scarman, "Bill of Rights and Law Reform" in R. Holme and M. Elliott, 1688-1988: Time for a New Constitution (1988); the Liberal Democrats, "We the People. . ." - Towards a Written Constitution (1990), and Reforming Governance in the UK, para. 2.2.2; Institute for Public Policy Research, A Written Constitution for the United Kingdom (1993).

31 Indeed, without such a text it is ". . . difficult to decide what counts as constitutional law in the United Kingdom": Eric Barendt, An Introduction to Constitutional Law (1998), p 28.

32 The composition of the state was, of course, further altered in 1922, but that was after the period under discussion. 
England had been settled, albeit that parliamentary democracy was limited. The formal constitutional instruments adopted abroad later that century were viewed by the English elite as the work of revolutionaries - and England had done with revolutions. ${ }^{33}$ Subsequent constitutional change, including the creation of Great Britain and later of the United Kingdom, and the extension of parliamentary democracy, could be and were achieved through ordinary exercises of parliamentary sovereignty, that is through the passage of ordinary legislation. ${ }^{34}$

Yet what may be seen now as a misalignment between, on the one hand, seventeenth and eighteenth century English political history and, on the other, the development of ideas about constitution-making was to be exacerbated by parliamentary developments in the nineteenth century. The party whip system ensured with increasing effectiveness that each political party in the House of Commons was loyal to its leaders and malleable. The absence of restraining constitutional rules was highly convenient for successive British Governments, which knew that they were able to deliver whatever they had promised in their election manifestos (and more) without having to make sure that their commitments were consistent with superior legal rules, and having to abandon any which were not. It is not too cynical to say that the absence of a codified constitution - which would be likely to limit the powers of Ministers and Parliament - came to be seen as agreeable to modern Governments: why should they risk that power by embarking on the search for a limiting constitution? ${ }^{35}$ Now politicians might find the argument a touch embarrassing expressed in that way, and it can be cast very differently. A codified constitution, it can be asserted, can be undemocratic, unlike the British arrangement which is wholly democratic. A political party can present its wares to the electorate at a General Election: if sufficient voters buy them, the resulting Government can cause Parliament to give legal force to them. ${ }^{36}$ This is the majoritarian argument writ large: that which most voters want they must be given, and no constitution must prevent it. By contrast, if the United Kingdom were to have a constitutional code which restricted the ability of the parties to offer exactly what they wished, then some policies might only be brought about if a constitutional amendment could be carried - a process which in most constitutions is notoriously hard to achieve. ${ }^{37}$ For instance, it might have been that some of the late Conservative Government's policies could not, through ordinary legislation,

33 See generally Linda Colley, Britons: Forging the Nation 1707-1837 (1992), chapter 4.

34 The term ordinary, or simple, legislation is used here to denote legislation enacted by the normal legislative process, as distinct from legislation designed to amend a constitution and which usually requires some form of special process.

35 This worry coloured Conservative and Labour attitudes to the incorporation of the European Convention on Human Rights. The Labour Party was concerned initially that the Convention might affect its ability to nationalize industry. The party's attitude to incorporation did not alter until the 1990s.

36 It is true that Parliamentary Counsel were directed to ensure that Bills were consistent with the European Convention on Human Rights. Parliament's sovereignty remains - at least in strict legal form - after the passage of the Human Rights Act (and related measures in Scotland, Wales, and Northern Ireland). But see note 76 .

37 See note 40 . 
have been implemented, such as the abolition of tiers of local government; ${ }^{38}$ nor might the present Labour Government have been able, by ordinary legislation, to have put into place most of its great constitutional reform programme. In that theoretical and alternative constitutional world those Governments might well have had to crank into operation the amendment mechanism which was provided, whether referendums ${ }^{39}$ or special parliamentary majorities. ${ }^{40}$

Now that defence of the status quo is based on the assumption that a codified United Kingdom constitution would necessarily involve significant limitations on government. Such limitations are generally considered to be desirable. But it would be possible to write a constitution for the United Kingdom which broadly preserved the balance of powers obtaining before its adoption. As such it would be conservative codification, a legal restatement of the constitutional status quo ante which did not alter its main provisions. The same point applies in relation to concerns about entrenchment. There is no ineluctable reason why a constitution must be entrenched against easy amendment or repeal, although again normally they are. It all depends on what decisions in principle are taken and what the resulting constitution prescribes: there is, of course, no template of a model constitution which must be followed slavishly. Once that fairly obvious fact has been asserted opponents of codification of the British constitution sometimes then switch the argument about entrenchment. They say that a written constitution is only worth having if it is entrenched, and then they assert the old point that it would be legally impossible to entrench a British constitution, given the unique nature of parliamentary sovereignty in the United Kingdom. ${ }^{41}$ In that case (the argument runs) what would be the point of subjecting the political process to the great effort of codifying an ancient constitutional settlement when the result could be altered by any Parliament through ordinary legislation at the behest of a subsequent Government? Attempts have been made to counter this canard: ${ }^{42}$ there are at least five ways through the constitutional conundrum. ${ }^{43}$ Indeed, in the contemporary political context

38 The Liberal Democrats would entrench local power in their proposed constitution: Reforming Governance in the UK, para. 2.2.2.

39 The Labour Government offered referendums on devolution to Scotland, Wales, and Northern Ireland, and to London, although it was not, of course, constitutionally required to do so; but no referendum was offered, $e g$, on House of Lords reform or the incorporation of the European Convention on Human Rights.

40 Typically the majority required may be a minimum of two-thirds of the membership of the relevant chamber of the legislature, as is the case in Germany (Basic Law for the Federal Republic of Germany, article 79(2)) and the United States of America (Constitution, article V). Even with its 179-seat majority, the Labour Government would be over 40 seats short of such a requirement in the House of Commons, and has had no majority at all in the House of Lords.

41 For an excellent survey of recent developments in the doctrine see A.W. Bradley, "The Sovereignty of Parliament - Form or Substance?" in J. Jowell and D. Oliver, The Changing Constitution (4th ed, 2000).

42 They are summarized, and my own suggestions to that end are made, in R. Brazier, Constitutional Reform (2nd ed, 1998), pp 149-156.

43 They include imposing a legal requirement on Ministers that they declare if any Bill would be incompatible with the constitution ( $c f$ the Human Rights Act 1998, s 19); or introducing an entrenchment mechanism and relying on Parliament to consider itself honour-bound to follow it; or using various legislative techniques 
the Labour Government's principal constitutional measures enjoy a form of protection, at least from possible assault by a non-Labour Government. No political party is likely to appeal to the voters with the battle-cries of "Abolish the Scottish Parliament, repeal the Human Rights Act, restore the hereditary peers!". ${ }^{44}$ Those, and other measures, enjoy the sanctity of the populist appeal represented by such things as the extension of national aspirations, or the protection of civil liberties, or the abolition of privilege. The Conservative Party has acknowledged that political entrenchment by, in effect, guaranteeing that the essence of those dispositions would remain undisturbed by a Conservative Government. ${ }^{45}$

The reluctance of the Labour and Conservative Parties to embrace full-blown constitutional codification does not seem to be based on concerns about the methodology which would be appropriate to the enterprise. ${ }^{46}$ Neither party has articulated concerns about how a code would be produced. But it is a vitally-important question which must be considered in this context. In part this is an issue of mechanics: how would a draft be arrived at, and how would it be approved? Resort could be had to an independent body which could prepare a text, ${ }^{47}$ or to a specially-elected constituent assembly of some

(such as the doctrine of implied repeal, or a direction to the judges to interpret legislation compatibly with the constitution, if possible ( $c f$ the Human Rights Act 1998, s 3)); and so on. Sir William Wade has suggested the simple idea of requiring all judges to take a new judicial oath which would oblige them to enforce an entrenchment provision: Constitutional Fundamentals (1989), chapter 3.

44 Perhaps from caution the rather weaker position of the Welsh Assembly should be mentioned. Given that, on a turnout of only $51.3 \%$, the people of Wales voted by only $50.3 \%$ to $49.7 \%$ in favour of the Assembly, it did not start its life with the same undeniable popular support as its Scottish or Northern Irish counterparts. It is conceivable that the Welsh Assembly may not survive.

45 This was the position taken by William Hague early in his leadership of the party, and confirmed recently: see his speeches "Change and Tradition" (Conservative Central Office, 1998) and "A Conservative View of Constitutional Change" (Conservative Central Office, 2000). He has given notice in that latter speech, however, that the Conservative Party will keep a close eye on the operation of the Human Rights Act, which he fears will undermine Parliament and give the judiciary too much power.

46 The Liberal Democrats have considered this question: see especially Here We Stand: Proposals for Modernizing Britain's Democracy (Liberal Democrat Federal White Paper No 6, 1993).

47 A Royal Commission would be the obvious vehicle: the Australian Constitutional Commission would provide an apt model: see note 84 . 
kind ${ }^{48}$ or the task could even be done within government. ${ }^{49}$ Once a text had been produced it could then be adopted by Parliament alone, although there would be a natural expectation (given in particular the use of referendums since 1997) that a national referendum would be held. ${ }^{50}$ While that mechanical question is very important, the more significant issue is rather different. Ideally a national constitution should be brought forth by national consensus, itself forged by a national purpose resulting from, for instance, the recognition that fundamental constitutional change is necessary, ${ }^{51}$ or the adoption of a new settlement on gaining independence, or the renewal of a state after collapse, ${ }^{52}$ or the confirmation of a fundamental change in the basis of the state. ${ }^{53}$ Through broad consensus among the people and political parties in a state the text should achieve a legitimacy which is denied to legislation passed by any transient parliamentary majority, and it should have greater durability, too. Similarly, the new constitution should achieve a special place in the legal system, marked out from other laws; any proposed changes to it will be recognized as raising constitutional, and not just political, issues; and, through entrenchment, it may be made legally more difficult to alter it. The paradigm case is that of the Constitution of the United States of America. ${ }^{54}$ It is my view that constitution-making ought to proceed by consensus if possible. ${ }^{55}$ But I am forced to acknowledge that no such national consensus or national purpose is likely to emerge in foreseeable circumstances in the United Kingdom. ${ }^{56}$ The political parties disagree on matters which would be the bases for crucial parts of the text. The Conservative, Labour and Liberal Democrat Parties disagree, for example, on the appropriate voting system for the House of Commons $;{ }^{57}$ the

48 Constituent assemblies, elected especially to draft a new constitution for a state, are a common device when a whole new constitution is required, rather than just reconsideration of part of an existing constitution.

49 The fundamental objections to such a course are that it would not be seen as open, inclusive, transparent, or cross-party.

50 Approval of constitutional change by referendums is a common feature of national constitutions, especially in continental Europe and in several Commonwealth states, including Australia.

51 The adoption of a new South African Constitution post-apartheid is an example of that.

52 As in France in 1958 following the collapse of the Fourth Republic.

53 Such as the joining of two states into one, as in the case of Malaysia in 1963, and Tanzania in 1964

54 Indeed, in the United States respect for the Constitution has, for many, become reverence. That makes amendment of it even more difficult to achieve than the formal amendment mechanism implies.

55 For the argument see Brazier, op cit note 42, chapter 2.

56 It is possible that a Government, minded to move towards constitutional codification, might seek all-party talks about it, but all-party agreement would be another matter.

57 The Liberal Democrats remain wedded to the goal of STV (see Reforming Governance in the $U K$, para 2.2.6). The Conservatives will defend first past the post in the last ditch. The Labour Government remains committed to the holding of a referendum before any change is made, but it will wait for the other voting systems introduced in the United Kingdom since 1997 to become familiar, and will allow time for all their consequences to be felt; consultations within the party disclosed "serious concerns" about the Jenkins Commission's AV-Top-up system 
Conservatives opposed reform of the House of Lords, and now that the first stage of it has been completed all the parties have different views on what proportion of the replacement body should be elected; ${ }^{58}$ the Conservatives oppose further devolution to England, ${ }^{59}$ whereas the Labour Government is taking it forward, slowly, while the Liberal Democrats cherish the ideal of a federal United Kingdom; the Liberal Democrats want a reduction in the constitutional power of the Monarch, but the other two parties do not; and so on. It is of course true that there has been much common ground between Labour and the Liberal Democrats since the mid-1990s on constitutional reform, leading to a joint body which published an agreed programme in $1997 ;^{60}$ and this co-operation carried over into the new Labour Government in the form of an unprecedented Joint Consultative Committee of the Cabinet on which Liberal Democrats sat with senior Ministers. ${ }^{61}$ But the question of a codified constitution does not appear to be one that has engaged them. That which still divides the three main political parties would make the sort of political consensus that I have described unachievable. ${ }^{62}$

But might there be a fall-back, or second-best, position? Could the ideal of a broadly-based acceptance of a text be brought about despite the divergence of views between the main political strands in the United Kingdom? The manner of adoption of the Constitution of the Fifth French Republic is instructive in this context. ${ }^{63}$ It was drafted largely to reflect the wishes of Charles de Gaulle in a body in which the representatives of the parties of the right were dominant. That draft was opposed by the Communists and by some Socialists, particularly on the ground that, unlike the Constitution of the Fourth Republic, the balance of power would be tipped decisively in favour a strong executive at the expense of a weaker legislature. In the subsequent national referendum held on the text some $79 \%$ of the French

(see Building a Future for All, p 159). Rumour has it that the choice to be offered will be between the status quo and the straight alternative vote.

58 The Liberal Democrats want to see an elected Senate (Reforming Governance in the UK, para 3.4); the Labour Government prefers a relatively small elected element (65 members) in an otherwise nominated second chamber (Building $a$ Future for All, p 157); the Conservatives want a larger elected element than Labour (see William Hague, "A Conservative View of Constitutional Change").

59 They propose "English votes for English laws" at Westminster as the answer to the West Lothian question, that is that MPs representing English and Welsh constituencies alone should vote on Bills affecting England and Wales only (Hague, ibid).

60 Report of the Joint Consultative Committee on Constitutional Reform (Labour Party and the Liberal Democrats, 1997).

61 According to Sir Paddy Ashdown that Joint Consultative Committee was an idea proposed by one of his advisers and suggested by Ashdown to Tony Blair, an idea which the new Prime Minister accepted. Indeed, according to Ashdown he and Tony Blair agreed until the day of the 1997 General Election that had Labour emerged as a minority party or one with only a small overall majority there would have been a Labour-Liberal Democrat coalition Government, an idea from which they both shrank at the last minute. See Paddy Ashdown, The Ashdown Diaries (2000), pp 493 et seq.

62 See further Brazier, op cit note 42, pp 5-7.

63 John Bell, French Constitutional Law (1992), chapter 1. For the political context as seen by a biographer of de Gaulle see Jean Lacouture, De Gaulle: The Ruler 1945-1970 (English ed, 1991), pp 193-206. 
people who voted approved it. When Francois Mitterand was elected some twenty years later as the first Socialist President of the Fifth Republic he made no attempt to alter the fundamentals of the Gaullist Constitution, which remains in its essentials as it was at its adoption over forty years ago. It could be argued that that Constitution had achieved the consensus in the referendum which politicians had failed to secure during the writing of it. That is a possible model for the adoption of a new Constitution of the United Kingdom. Those who opposed the draft might accept defeat gracefully, falling in with the people's wish if it were that the text should be adopted, just as happened in France. ${ }^{64}$ Indeed, there is a modern British analogy for such acquiescence: this is what the Conservative Party has done since 1997, accepting not only the Labour Government's constitutional changes which had been approved at referendums but also those that had not been. The Conservatives fought that Election as determined champions of the then status quo ${ }^{65}$ which was a principled stance which had been taken by the party since it took its modern form in the nineteenth century. But they recognized after the Election that they had lost the argument.

Such a neat solution to the search for consensus, however, omits a possible prior political decision by the main Opposition party. Might it not so oppose the codification exercise that it would refuse to take any part in the process? Might it boycott the search for a text, whether that quest was to be conducted through Parliament itself or through a specially-convened commission or elected constituent assembly? After all, that is precisely what the Conservative Party, together with the Scottish Nationalists, did when they were invited to join the Scottish Constitutional Convention which went on to write detailed plans for what became the Scottish Parliament. ${ }^{66}$ Indeed, Conservative-Labour co-operation on constitutional matters has not been seen since 1936, when Stanley Baldwin ensured that all three party leaders took the same approach towards the abdication crisis - although wherever possible all Prime Ministers have tried to ensure that the constitutional problems of Northern Ireland have been approached on an all-party basis. ${ }^{67}$ A refusal to join a codification exercise would preserve the party's ability to fight the text in the last ditch, if necessary, but whether to do so would be a matter of political judgement. It would retain the purity of its opposition: but it would lose any ability to influence the resulting text, which for all the party could know might prove acceptable to voters.

The issue of whether to codify the United Kingdom constitution inevitably raises the question of what would be done in that process with constitutional

${ }^{64}$ But it has been said that the 1975 referendum on continued membership of the European Community did not cause all those on the losing side to accept the result with good grace: Dawn Oliver, Government in the United Kingdom (1991), p 108. Many Eurosceptics still oppose membership, and there remain gradations of opposition to the European Union.

65 The essence of their case was that the constitution was working perfectly adequately, and that as and when a problem was identified it could be corrected by legislation passed for the purpose.

66 McFadden, "The Scottish Constitutional Convention" [1995] PL 215.

67 Michael Heseltine offered all-party talks on a replacement for the poll tax, but Labour refused to take part: see Michael Heseltine, Life in the Jungle (2000), pp 388-389. 
conventions. This is a particular problem for the United Kingdom because of the heavy reliance which is placed on those non-legal rules, although even written constitutions attract conventions to them. If a codified constitution for the United Kingdom were to be embarked on a number of possibilities would present themselves to deal with the conventions. ${ }^{68}$ The easiest by far would be to leave them (or at least most of them) outside the code, so that they would continue to enjoy the same status and functions as now. To the extent that any existing convention was later discovered through experience to be incompatible with the new constitution, it would disappear just as any redundant convention disappears. The principal drawback with such a solution, however, is that the present disadvantages of constitutional conventions - imprecision, the room for disagreement whether a convention exists and if so what it ordains, and inaccessibility - would remain. Alternatively, some of the most important conventional rules could be incorporated into the constitutional code, leaving others outside it. Again, in theory all the principal conventional rules could be reduced to rules of law (whether in the constitutional code itself or in statute). But that would be unwise: it would introduce certainty while sacrificing the flexibility which is rightly claimed as an advantage of constitutional conventions, and it would also open the door to justiciability of issues many of which are overwhelmingly political and not suited to judicial intervention. ${ }^{69}$ Lastly, therefore, some other authoritative, but non-legal, statement might be made of the major United Kingdom constitutional conventions. That would be my preferred option. ${ }^{70}$ This is what was done in Australia, which has a formal but non-justiciable statement of the main constitutional conventions concerning federal government. ${ }^{71}$ There is no dearth of answers to the question of what to do with conventional rules in any constitutional codification process, and the conventions do not erect a barrier to such an enterprise.

\section{PROSPECTS FOR A NEW CODE}

The Labour Party is the odds-on favourite to win the forthcoming General Election. For that reason its likely attitude to a grand project of working towards a constitutional code for the United Kingdom is clearly worth examining more closely.

As has been indicated, there are undoubtedly those in the Labour Party and the Government who think that, shortly put, "We have done enough constitutional reform". Certainly, the party cannot be accused of giving insufficient priority, in terms either of parliamentary time or of parliamentary

68 See Brazier, "Enacting a Constitution”, 112-113.

69 There is an important precedent in which the judiciary recognized that some matters are best left in the political arena rather than being subjected to judicial review: Council of Civil Service Unions v Minister for the Civil Service [1985] AC 374 (aspects of the royal prerogative: national security, and matters such as the dissolution of Parliament and the grant of honours).

70 Brazier, op cit note 42, pp 27-28.

71 Sampford, "'Recognize and Declare': An Australian Experiment in Codifying Conventions" (1987) 7 Oxford Journal of Legal Studies 369. In 1983, 33 conventions were formally declared in writing. Inevitably the statements of some of the conventions were more helpful than others. 
priority, to constitutional change. ${ }^{72}$ This Government already has a place in the constitutional history of the United Kingdom for producing within a few years of one Parliament more constitutional law of basic importance than any other Government or Parliament before it. Even those who have opposed the substance of that record must give credit to the Government for according constitutional affairs the serious consideration which they deserve. There are, too, Labour people who believe, rather grudgingly, that constitutional reform has enjoyed the place it has in the work of the present Labour Government partly as a legacy of John Smith's leadership, ${ }^{73}$ especially in relation to devolution, and they will probably think that any debt to him has been fully paid already. There is also the view that enough is enough simply because, in terms of party advantage, some of the changes have backfired, and that it would have been better to have left some of the old constitutional rules alone. It is clearly the case that the Labour Party has ceded political power away from Westminster, and that it has not done well wherever the voting system has been altered from first past the post to any more proportional system. Not only has legislative authority been "lost" to Edinburgh and Cardiff, ${ }^{74}$ but the party has had to form coalitions with the Liberal Democrats in the Scottish Parliament and in the Welsh Assembly (having failed to keep a minority Labour administration going in Cardiff), all thanks to the use of the additional member system of elections. ${ }^{75}$ The Government's European Parliamentary Elections Act 1999 resulted in the Conservatives doing well in the elections of that year under the regional list system. The Government's candidate for London Mayor was trounced in part because of the supplementary vote provided under the Greater London Authority Act 1999. Parliament itself will lose further power - this time to the judges - as a result of the Human Rights Act. ${ }^{76}$

But even Ministers who might wish to avoid further constitutional change will have to accept a number of other constitutional initiatives in the next Parliament. Stage two of Lords reform will be controversial both inter-party and intra-party, and significant amounts of parliamentary time will be needed for the legislation. ${ }^{77}$ There may, too, have to be debates about, and possibly

72 Indeed, the first Bill introduced into Parliament by the new Labour Government in 1997 was the Referendums (Scotland and Wales) Bill.

73 He was passionately committed to devolution, and became a champion of the incorporation of the European Convention on Human Rights.

74 This sort of analysis does not apply to Northern Ireland, for all the main London parties have accepted that some form of devolution of power to Belfast is essential.

75 Scotland Act 1998, ss 1, 2 and Schedule 1; Government of Wales Act 1998, ss 1, 2 and Schedule 1. Proportional representation was well-known in Northern Ireland, and the use of it for elections to the Northern Ireland Assembly was unexceptional as well as essential.

76 Although declarations of incompatibility are only advisory, in practice the Government will be under considerable political pressure to legislate to make the law compatible with declared Convention rights. Perhaps parliamentary sovereignty in this context has been passed, in effect, to the judges by sleight of hand under the regime adopted in the Human Rights Act.

77 The legislation will be preceded by a joint select committee of both Houses. The Government started negotiating its terms of reference with the Opposition and other parties in the summer of 2000, but no agreement was reached before the end of the 1999-2000 session. The Government says that it will proceed on the basis 
legislation to provide for, a referendum on a different voting system for Westminster. ${ }^{78}$ Depending on circumstances, legislation might also be required to allow for a referendum on whether the euro should be adopted. ${ }^{79}$ Accordingly, a new Labour Government, whether certain Ministers liked it or not, would have a significant constitutional reform agenda before it. That would mean that a constitutional codification project would have to compete with unavoidable constitutional work. That said, no legislation about a new constitution would be needed before, at the earliest, late on in the next Parliament, or more likely until a subsequent Parliament, because of the preparatory work which would have to precede it. ${ }^{80}$

Any likely codified constitution would probably contain provisions which would be inconvenient for any Government. Of course, this point is wholly dependent on what went into the text, but it seems more likely that if the United Kingdom went back to first principles ${ }^{81}$ there would be some transfer of power away from the central executive. Take, for instance, the matter of the royal prerogative. ${ }^{82}$ It is notorious that many powers exercised by Ministers are prerogative-based, and that Parliament has precious little control over the use of such powers. Is it credible that a codification would confirm that massive accretion of power in the hands of the Government, without at the very least the introduction of greater democratic control? ${ }^{83}$ The analysis of the current situation which a codification would require would at the very least further expose this imbalance of authority and require Ministers to try to defend that which is difficult to defend. That would be uncomfortable for the Government, and thus for a likely Labour Government in its second term.

Over any suggestion of a full-blown codification would be cast the prudent eyes of the Treasury. Accurate costings are impossible to suggest, for they would depend on exactly how the process was to be conducted. If, for example, something along the lines of the work of the Australian Constitutional Commission ${ }^{84}$ were to be employed to do the detailed work on

of consensus and consultation, and that the timing of further progress will depend on the outcome of it: Building a Future for All, p 157.

78 See note 57.

79 See note 87.

80 That point will be looked at shortly.

81 It is perhaps more accurate to speak of addressing first principles for the first time, given that at no stage in the constitutional development of the United Kingdom has any comprehensive consideration of the constitution been undertaken.

82 See A. Tomkins, "Crown Privileges" and R. Brazier, "Constitutional Reform and the Crown" in M. Sunkin and S. Payne (eds), The Nature of the Crown (1999); R. Blackburn and R. Plant, "Monarchy and the Royal Prerogative" in Blackburn and Plant (eds), Constitutional Reform: The Labour Government's Constitutional Reform Agenda (1999). For a ministerial defence of the use by Governments of the royal prerogative see 223 HC Debs 489-494 (21 April 1993).

83 Two existing drafts of a possible United Kingdom Constitution would deal with prerogative powers by (i) making the proposed new text the sole source of power in the state, (ii) then conferring specific powers on (for example) the head of state or the Prime Minister, and then (iii) abolishing the prerogative as a source of legal authority. See Institute of Public Policy Research, A Written Constitution for the United Kingdom (1993), article 1; Liberal Democrats, Here We Stand.

84 Australian Constitutional Commission, Final Report (1988). 
a possible draft, involving the appointment of an independent body, consulting widely, the use of expert committees, publication of consultation documents, and consequent referendums, then millions of pounds would be needed.

It is easy to see why some commentators have viewed the adoption of a codified United Kingdom constitution as unlikely. ${ }^{85}$ Some people have argued against trying to achieve it because doing so would divert energies from the reform of particular constitutional rules, which they say is a more urgent cause. ${ }^{86}$ That second point - quite right when deployed even a few years ago - has been weakened by Labour's constitution-making since 1997. The Labour Government has devoted energy to specific projects of constitutional change where it judged the most necessary work was needed. And so how, in today's circumstances, can the argument for a codified constitution be expressed?

Once again it makes the most practical sense to consider that question primarily from the perspective of the Government: what, politically, might Labour have to gain from a commitment to such a grand project? First, such an initiative would be an historic one, confirming the Labour Government's modernizing credentials. For the first time a Government would promise a fundamental review of the historic constitution, free from the exigencies of awkward political events that heretofore have forced piecemeal changes. In the process some of the Liberal Democrats' clothes would be stolen, and the Conservative Party would receive a fresh challenge to its constitutional conservatism. Secondly, such a policy would not in fact commit the Government to very much in practical terms. It would be a long time before Ministers had to react to any result of a comprehensive review. Because of the scale of the enterprise no action would be required to give effect to any recommendations for a number of years. And it must always be kept in mind that very few advisory inquiries bind a Government for political reasons to act on their recommendations. Depending on the methodology, no text might be ready for public or parliamentary consideration even in the next Parliament; if the drafting were to be conducted outside Parliament the result would have to be assessed by Parliament, whether by a joint select committee of both Houses or otherwise. Then there might be a referendum on the text, but even that might be made conditional on the Government feeling able to commend the draft to the nation, rather like Ministers' attitude to the possible adoption of the euro. ${ }^{87} \mathrm{~A}$ referendum would require legislation to provide for it. In short, a commitment to see what a codified

85 For instance, Dawn Oliver, Government in the United Kingdom, pp 200-201: "The reality of the matter is that the adoption of a Constitution is unlikely to become politically attractive for many years, if at all. .."; Robert Hazell, "The New Constitutional Settlement" in Hazell (ed), Constitutional Futures: The History of the Next Ten Years (1999), pp 239-240: "[The Labour Government's constitutional reforms] amount to a series of steps towards a written constitution, ... [but they are] not likely to result in a written constitution, in the sense of a single codified document."

86 For example, Oliver, ibid.

87 The Government describes the adoption of the euro as being subject to triple approval, of the Government, Parliament, and the people (through a national referendum). 
United Kingdom constitution might look like would require the Government to agree to little more in practical terms than to initiate an inquiry and to find out; if the result were not to Ministers' tastes they could decline to take the matter any further. A third party-political point is that Labour Ministers would avert any danger that the Conservative Party might outflank the Government and make such a project its own. ${ }^{88}$ While such a move by the Conservatives might seem unlikely, it might be adopted in part as a desire to limit the power of government - a policy that could appear increasingly attractive the longer a Labour Government was in power. A final party point is that, while an outright Labour victory at the next General Election appears likely, support from the Liberal Democrats might be desirable or even essential if there were a close result or a hung Parliament. The Liberal Democrats have already embraced the codification ideal, and they would find such a commitment by Labour attractive, although admittedly not as attractive as moves towards a more proportional voting system for Parliament.

For the sake of completeness, it can be noted that membership of the European Union is unlikely to affect the prospects for a codified United Kingdom constitution. In making up its mind whether to take such a project further, the European Union will be a neutral factor for the Government. European Union membership has not required, and will not require, member states to do things to the form of their national constitutions that they would not otherwise have done. Of course, making European Community law sovereign over national law was a supremely important matter, in the United Kingdom as elsewhere. Other laws have been given force in member states as a consequence of membership, but by and large they are not of a constitutional character. ${ }^{89}$ The acceptance of a single currency, too, has been a major constitutional matter - and an unprecedented one, given that sovereign states who have adopted it have harmonized their money before they have adopted a common constitution, thus putting economics before politics. ${ }^{90}$ But membership of the European Union is unlikely to require any state to alter the format of its national constitution: the United Kingdom is not likely to move towards a codified constitution solely or even primarily as a result of that membership.

The old arguments about whether the British constitution should be codified, or whether its sources should be left just as history has made them, are well-

88 There is no evidence currently in the public domain that the Conservative Party would initiate such a policy. But there is an intriguing passage in William Hague's speech "A Conservative View of Constitutional Change". In the context of wishing to reserve certain powers for the British Parliament as against the European Union he spoke of writing into law the powers and rights we hold today and which would be reserved permanently to the United Kingdom. That could be done by amendments to the European Communities Act 1972; it could hint at something more radical.

89 There are examples of new constitutional laws which have been adopted to reflect the obligations of membership, such as providing for a common system to elect Members of the European Parliament.

90 This is why comparisons with the states of the United States enjoying a common currency with benefits for all of them is fallacious: federation preceded the acceptance of the dollar, not the other way round. 
known, and they remain. But those arguments were rebalanced somewhat at the turn of the last century. A reforming Government altered many constitutional rules, and thereby added to the statute-base of the British constitution. In doing that, significant parts of any constitution - such as a Bill of Rights, and the legal delineation of power between different geographic parts of the state - have been added to the constitution of the United Kingdom. In doing all that, the apparent taboo which had seemed to prevent British Governments from making planned changes to the constitution was broken. Someone contemplating a wager on whether the United Kingdom might give itself a codified constitution in the foreseeable future would have to weigh the historical evidence against recent developments such as those before deciding whether to risk a bet. The odds are still against a new constitutional code, but perhaps it can be said that they have shortened. 